\title{
VITAL PULPOTOMY IN PRIMARY TEETH WITH MINERAL TRIOXIDE AGGREGATE (MTA)
}

\author{
Kabaktchieva R., Gateva N. \\ Department of Pediatric Dentistry, Faculty of Dental Medicine - Sofia
}

\section{SUMMARY}

Mortal pulpotomy is the most commonly used technique in Bulgaria for treatment of pulp chronic infections in primary teeth. Data from the special literature reveal another method for pulp treatment in primary teeth - vital pulpotomy associated with good adaptive healing response. During the past several years, special attention has been paid to Mineral Trioxide Aggregate -MTA as probable alternative of formocresol. According to the current trends in dental medicine about cessation of arsenic usage and limitation on formalin - containing medicaments usage, there will be a revision of commonly used method of mortal amputation, including application of arsenic, tricresolformalin, resorcine or resorcine-formalin solutions.

The aims of this study are to aprobate and popularize the technique of vital pulpotomy in primary teeth with MTA.

The study was carried out with children (the children's age was $4-8$ years) with primary molars approximately equally affected by a carious process which had reached the dental pulp and had to be treated. The total number of studied primary teeth was 33 .

The methodology is "one visit" and was performed following equal clinical protocol for all teeth. The pulp stump was covered with an MTA paste- Angelus (Solucoes Odontologicas, Londrina, Brazil), prepared by mixing MTA powder with sterile saline using 3:1 powder/saline ratio. Restoration of the teeth was performed with GIC. All treated teeth were follow-up clinically and radiographically during 6 months, at 6 and 12 month after vital pulpotomy.

Results: The success rate of all pulpotomized teeth with MTA was $100 \%$ after 6 months and shows statistically insignificant decrease to $90,9 \%$ after 12 months ( $p>0,05)$. The number of teeth with unsuccessful treatment is 3 or 9,1 $\%$.

Conclusion: Vital amputation with MTA is a reliable biological method for pulp treatment of primary teeth and could be recommended for the clinical practice.

Despite the advance in knowledge about the onset, nature, progression, prevention opportunities and nonoperative treatment of carious process, the disease and its complication are still main clinical problem (23). Extensive dental decay in the primary dentition, that reaches and progresses to the dental pulp, remains a serious problem in pediatric dental practice $(2,28)$. Currently, there is not generally accepted methodology for pulp therapy in primary teeth. The traditional endodontic approach to manage pulp infection in primary teeth is by surgical amputation of the coronal pulp - pulpotomy $(3,23,29)$.

Mortal pulpotomy is the most commonly used technique in Bulgaria for treatment of pulp chronic infections in primary teeth $(1,3,5)$. Data from the special literature reveal another method for pulp treatment in primary teeth - vital pulpotomy $(4,15,18,26,34,66,40)$. The aim of the vital pulpotomy is, by removal of the inflamed coronal part of the pulp and putting a pulp dressing, to preserve the root part of the pulp which is not inflamed in order to fixate its coronal parts and keep the vitality of the apical parts $(4,13,44)$. There are several techniques for pulp treatment in primary teeth with different clinical protocols and medicaments used for the various clinical situations $(3,4,18,26,34,40,63,66)$.

Primary teeth treatment with fomocresol pulpotomy is commonly accepted method in many countries from the past 60 years $(3,4,11,22,23,27,28,48)$. More insistently, the current studies present information and guidelines for limitation on formocresol technique for vital amputation, because of the evidence gained from animal testing the mutagenic, carcinogenic, immunogenic and toxicity potential of formaldehyde $(32,36,48,55,65)$. The isolated formaldehyde is the active component of medicaments used in Bulgaria for pulp treatment.

In order to find an alternative medicament, that guarantee the radicular pulp preservation in primary teeth until the time of their physiological exfoliation, as well as to avoid the side effects from formalin-containing medicaments and cessation of arsenic usage (a toxic medicament), various medicaments acting as wound dressing in primary teeth pulpotomy are presented. Different agents and methods electrosurgery, laser, glutaraldehyde, ferric sulphate, freezedried bone, bone morphogenic protein and osteogenic protein have been studied $(12,17,21,23,25,27,37,44,50$, $55)$.

It is generally accepted that less invasive technique should be use, associated with good adaptive healing response of the affected primary tooth $(4,15,27,40,44,63)$.

Recently, with improvement of medicaments, that are not only biocompatible, but also bioinductive, the focus has been directed from preservation and conservation to 
regeneration of the remaining pulp tissue $(23,29,30,53,59)$.

During the past several years, special attention has been paid to MTA usage in endodontic treatment of permanent teeth $(9,20,52,54,56,67)$, as well as probable alternative of formocresol in primary teeth vital pulpotomy $(6,7,19,23,29,38,39,43,56)$.

Mineral trioxide aggregate (MTA) was developed and introduced in 1993 at the Loma Linda University, California, USA, as a root-end filling material and was approved by The US Food and Drug Administration for human teeth treatment application in $1998(7,23,53,55,59)$. MTA is biocompatible material and its sealing ability is superior to amalgam or zinc oxyde eugenol (ZOE) $(7,10,24,58,59,61)$. It was found that MTA has the ability to stimulate the release of cytokines from bone cells, which demonstrates the active assistance of MTA in hard tissue formation $(7,29,31,35,60)$.

The compound of MTA is a mixture of tricalcium silicate, dicalcium silicate, tricalcium aluminate, calcium sulfate dehydrate, gypsum and bismuth oxide $(14,29,49,55)$.

The commercial products with MTA are: ProRoot MTA (Dentsply Tulsa Dental, Tulsa, OK, USA); White ProRoot MTA (Dentsply Tulsa Dental); MTA-Angelus (Solucoes Odontologicas, Londrina, Brazil); MTA-Angelus Blanco (Solucoes Odontologicas); MTA Bio (Solucoes Odontologicas). In the market there are two forms of MTA white and gray.

In Bulgaria complications from dental caries in primary teeth have high prevalence. According to the current trends in dental medicine about cessation of arsenic usage and limitation on formalin - containing medicaments usage, there will be a revision of commonly used method of mortal amputation, including application of arsenic, tricresolformalin, resorcine or resorcine - formalin solutions.

The aims of this study are to aprobate and popularize the technique of vital pulpotomy in primary teeth with MTA.

To achieve the aims of this study, the following tasks have been set:

1. To review the dental literature and to present the newest studies and their results about the success and disadvantages of vital pulp therapy with MTA in primary teeth.

2. To perform vital pulpotomy with MTA on primary teeth with carious complications.

3. To test the clinical results on 6 and 12 months after MTA pulpotomy.

\section{MATERIALAND METHOD:}

Realization of the first task requires electronicscreening using key words of the special literature published after 1993 for studies and articles in relation to characteristics and clinical applications of MTA in pediatric dental practice.

The study was carried out with children with primary molars approximately equally affected by a carious process which had reached the dental pulp and had to be treated. The total number of studied primary teeth was 33 , but this number did not correspond to the number of examined children, because some of them had more than one tooth needing pulp treatment. The children's age was $4-8$ years, they were healthy, without signs of systematic diseases and with positive attitude toward dental treatment. Treatment plan in details, possible feeling of discomfort and treatment stages were explained to the parents and to the children. The parents gave their informed consent. Diagnostic and treatment protocols, as well as re-call observations were performed by two specialists in pediatric dentistry.

Selection criteria for the examined teeth were:

1. Primary teeth with deep carious lesion: no history of spontaneous or night pain, swelling, presence of fistula or tooth mobility

2. Primary teeth with vital pulp exposure as a result of carious process, with hemorrhage at the site of exposure

3. No clinical signs or evidence for total pulp inflammation (prolonged hemorrhage) or pulp degeneration (percussion sensitivity).

4. Absence of radiographic evidence for internal or external root resorption or radiolucency in furcation area.

5 . No more than $1 / 3$ physiological root resorption

6. Possibility for further tooth restoration

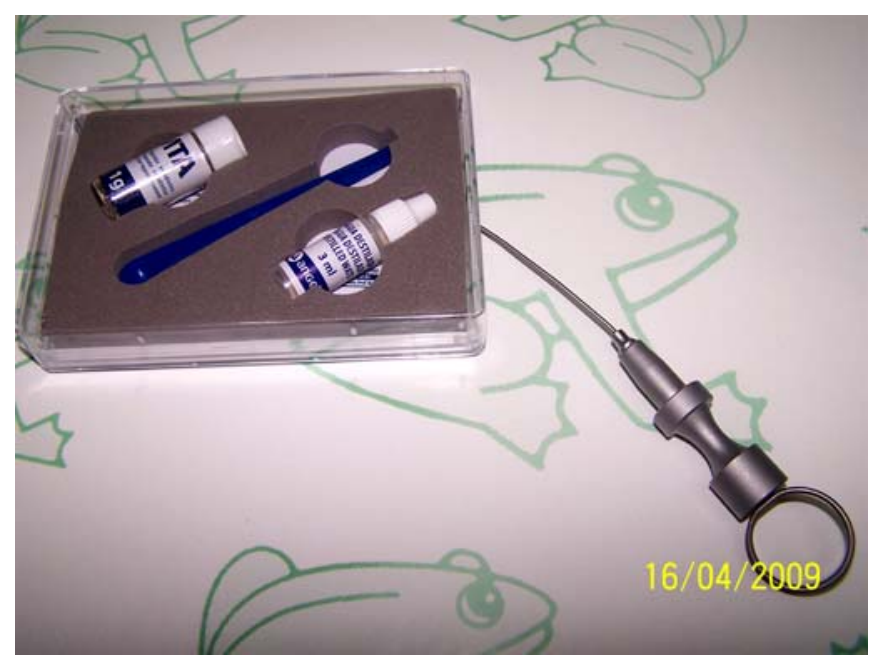

Fig. 1. MTA - Angelus (Solucoes Odontologicas, Londrina, Brazil)

\section{CLINICAL PROTOCOL}

The methodology is "one visit" and was performed following this clinical protocol. Administration of local anesthesia for effective pain control. After removal of the carious tissues, the pulp chamber was accessed with bur $\mathrm{N}^{\circ} 330$, high speed handpiece and water spray. Following removal of the coronal pulp with an excavator or round bur, hemostasis was obtained using cotton pellets soaked in saline solution. The pulp stump was covered with an MTA paste- Angelus (Solucoes Odontologicas, Londrina, Brazil), 
prepared by mixing MTA powder with sterile saline using $3: 1$ powder/saline ratio (fig. 1 ). The manufacturers recommend mixing $0,33 \mathrm{~g}$ water with $1 \mathrm{~g}$ MTA to achieve optimal material mix. For optimal hardening of MTA manufacturers recommend placement of wet cotton pellets in cavum pulpae for a short period before application of MTA. Restoration of the teeth was performed with GIC.

\section{Treatment approach philosophy}

Vital pulpotomy in primary teeth is necessary to achieve adaptive biological response from the pulp-dentinal complex of treated tooth, to stabilize the affected tooth and to create favourable conditions until the time of its natural exfoliation.

\section{Treatment follow-up}

All treated teeth were follow-up clinically and radiographically during 6 months - at 6-th and 12-th month after vital pulpotomy.

The clinicians made their independent evaluations of the treated teeth using definite clinical criteria, and together they evaluated the radiographic images of the treated teeth until reaching a consensus.

Clinical criteria for successful pulp therapy are:

1. No pain

2. No percussion sensitivity

3. No swelling and/or fistula

4. No pathologic tooth mobility

Radiographic criteria for successful pulp therapy are:

1. No translucency in furcation area

2. No internal or external root resorption

3. No widening of periodontal space

As unsuccessful was referred treatment with one of the clinical or radiographic criteria described above. The data were recorded in patients' documentation and serve as a basis for evaluation at re-call visits.

\section{RESULTS}

The literary review about studies and results for success and disadvantages of vital pulp therapy with MTA in primary teeth is presented in Table 1 .

Table 1. Pulpotomy in primary teeth - studies of different authors

\begin{tabular}{|c|c|c|}
\hline Clinical application & Studies & Evidence \\
\hline \multirow[t]{17}{*}{$\begin{array}{l}\text { Pulpotomyprimary } \\
\text { teeth }\end{array}$} & $\begin{array}{l}\text { Prospective studies comparing } \\
\text { MTA to formocresol }\end{array}$ & Studies in teeth with carious pulpal exposures \\
\hline & & Clinical success outcomes \\
\hline & Eidelman et al. $2001^{19}$ & Grey: $>90 \%$ over $6-30$ months \\
\hline & Agamy et al. $2004^{7}$ & $\begin{array}{l}\text { Grey: } 100 \% \text { over } 1 \text { year. } \\
\text { White: } 84.2 \% \text { over } 1 \text { year }\end{array}$ \\
\hline & Holan et al. $2005^{29}$ & Grey: $97 \%$ over $4-72$ months \\
\hline & Farsi et al. $2005^{22}$ & Grey: $100 \%$ over 2 years \\
\hline & Peng et al. $2006^{46}$ & MTA: $95 \%$ at laest 6 months follow-up period \\
\hline & Aeinehchi et al. $2007^{6}$ & Grey: $100 \%$ over 6 months \\
\hline & Noorollahian, $2008^{43}$ & White: $100 \%$ over 2 years \\
\hline & Subramaniam et al., $2009^{57}$ & MTA: $95 \%$ over 2 years \\
\hline & Prospective longitudinal studies & \\
\hline & Maroto et al. $2005^{38}$ & Grey: $100 \%$ over 6 months \\
\hline & Maroto et al. $2007^{39}$ & White: $100 \%$ over 42 months \\
\hline & Prospective study comparing MTA to $\mathrm{Ca}(\mathrm{OH}) 2$ & \\
\hline & Percinoto et al. $2006^{47}$ & Grey: $95 \%$ over 1 year \\
\hline & $\begin{array}{l}\text { Prospective study comparing MTA to FC } \\
\text { and } \mathrm{Ca}(\mathrm{OH}) 2\end{array}$ & \\
\hline & Moretti et al. $2008^{41}$ & Grey: $100 \%$ over 2 years \\
\hline
\end{tabular}

The literary data about clinical evaluation of MTA demonstrate:

- High success rate (clinically and radiographically) of MTA as pulp-capping agent in primary teeth pulpotomy. - MTA could be a substitute for formocrelol as a pulpcapping agent on primary teeth 
- MTA doesn't lead to internal root resorption.

The literary data about histology evaluation of MTA usage demonstrate:

- MTA shows no mutagenic or cytotoxic properties

- MTA is biocompatible and suitable material for perforation healing, as it induces very slight inflammation, even if overextended in the perforation area

- In vitro studies of human odontoblasts show that MTA stimulates synthesis of cytokines and interleukin products.

- MTA stimulates hard tissue formation - release calcium in form of calcium hydroxide.

- MTA stimulates formation of "dentinal bridge" and preserve the vitality of the remaining pulp tissue.

Available evidences suggest that formocresol, calcium hydroxide and MTA have comparable effectiveness in vital pulpotomy of primary teeth.

After 6 months 33 teeth were follow-up -100\% of treated teeth. All of these teeth were assessed clinically and radiographically as successful - with no fistula, swelling or inflammation of the surrounding gingival tissue, pathologic mobility, tenderness in percussion, as well as external and internal root resorption or widening of periodontal ligament space (Table 2).

After 12 months clinical and radiographic evaluation were performed on 30 teeth. The other 3 teeth were assumed as teeth with unsuccessful treatment and postoperative healing period, because of: 1 tooth with pain, 2 teeth with high degree of mobility and presence of inflammation in gingival tissues (Table 2). One of these teeth was extracted and the others were treated with resorcin -formalin method. Clinical and radiographic evaluation for the other 30 teeth shows successful healing process in pulp tissue (table 3 ).

Table 2. Results from the clinical evaluation

\begin{tabular}{l|l}
$\cdot$ After 6 months & $\cdot$ After 12 months \\
-33 asymptomatic teeth & $-90,9 \%$ success \\
- all teeth are assessed clinically and & -30 asymptomatic teeth \\
radiographically as successful & -1 tooth present with pain \\
$-100 \%$ success & -2 teeth with high degree of mobility and marginal \\
& gingiva inflammation \\
& $-90,9 \%$ success
\end{tabular}

Table 3. Clinical and radiographic results

\begin{tabular}{|c|c|c|c|c|c|c|c|}
\hline \multicolumn{5}{|c|}{ Radiographic sign } & \multicolumn{3}{|c|}{ Clinical sign } \\
\hline $\begin{array}{l}\text { number of teeth } \\
\text { examined }\end{array}$ & $\begin{array}{l}\text { internal root } \\
\text { resoption }\end{array}$ & $\begin{array}{l}\text { radiolucency in } \\
\text { furcation zone }\end{array}$ & $\begin{array}{l}\text { radiolucency in } \\
\text { periapical zone }\end{array}$ & $\begin{array}{l}\text { root canal } \\
\text { obliteration }\end{array}$ & pain & swelling & fistula \\
\hline 12 month -30 & - & 1 & - & - & 1 & 1 & - \\
\hline
\end{tabular}

The success rate of all pulpotomized teeth with MTA was $100 \%$ after 6 months and shows statistically insignificant decrease to $90,9 \%$ after 12 months ( $p>0,05)$. (Diagr. 1). The number of teeth with unsuccessful treatment is 3 or $9,1 \%$. The authors associate the unsuccessful cases with compromise made with the clinical protocol, as well as including teeth with boundary criteria as indication to be included in the experiment, frequently - prolonged bleeding from root canal pulp tissues.

Diagram 1. $\rightarrow$ Results from clinical and radiographic follow-up.

We represent a successful clinical case of pulpotomy with MTA (fig. 2.).

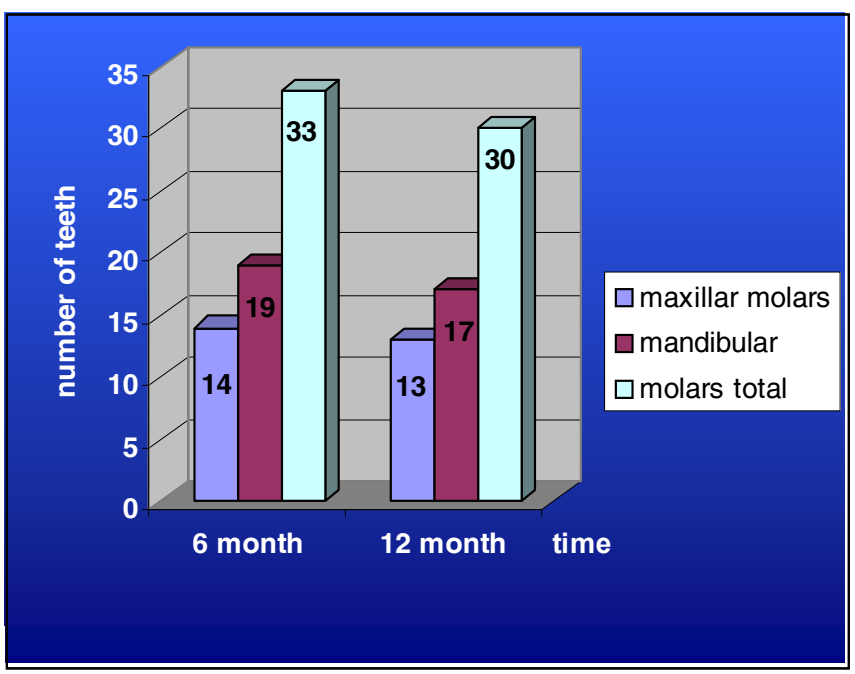




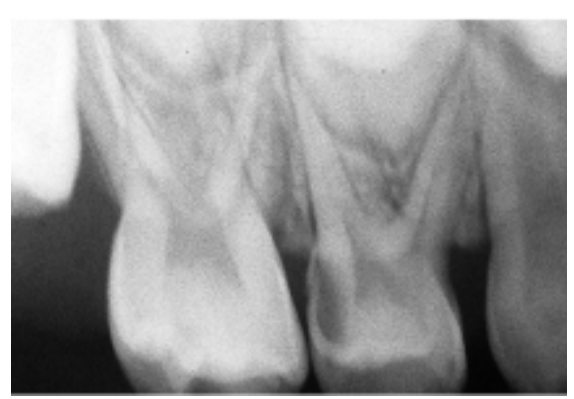

(a.) 5 years of age

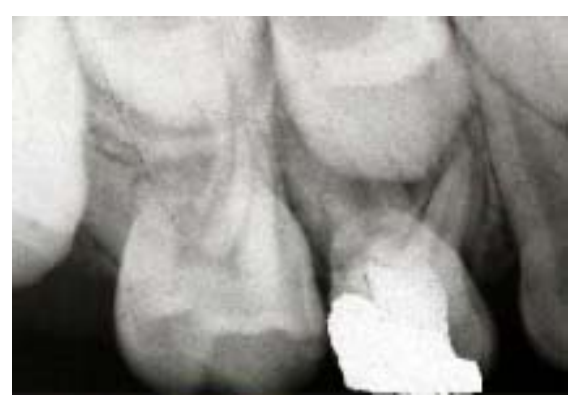

(b.) 5,5 years of age

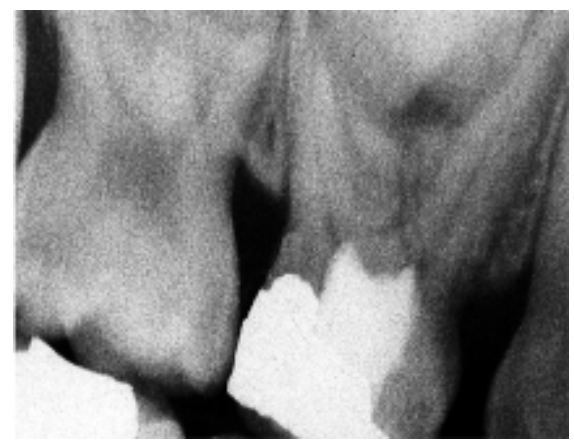

(c.) 6 years of age

Fig. 2. A clinical case of child (B. C.) at: (a.) Preoperative Ru.gr - deep carious lesion on tooth 54; (b.) Postoperative Rц.gr on tooth 54 after 6 months; (c.) Postoperative Rщ.gr on tooth 54 after 12 months;

\section{DISCUSSION}

The study represents clinical and radiographic success rate of pulpotomy with MTA in primary teeth. MTA is a material with proven therapeutic properties in different endodontic procedures of primary teeth already $(6,7,19,23$, $29,38,39,41,43,47,56)$.

We have chosen a pulpotomy with MTA, because MTA has not toxic side effects - systematic or local, this pulpotomy has shorter clinical protocol and excellent therapeutic effect (according to literary review) $(33,45,51$, 56 ).

The commercial price of 1 gr. MTA-Angelus (Brazil) is 99 leva, this amount MTA is enough to perform 15 pulpotomies and this means that the mean price is 6 leva per tooth.

To achieve an optimal solidity and compressive strength, some authors suggest waiting for 24 hours before definitive restoration of the tooth $(16,59,64)$. We preferred for the definitive restoration the conventional GIC, because it could be placed on partially hardened MTA in one-visit procedure (according to literary data) and this way allows undisturbed hardening of MTA below $(8,42,56,62)$.

Data from special literature review about the results from pulpotomy with MTA in primary teeth, report high success rate $94-97 \%$ for the observation period $24-32$ months $(6,7,19,23,29,38,39,41,43,47,56)$.

The results of this study show success rate of 90,9 $\%$ for one year follow-up period.

\section{CONCLUSION}

- The current study shows high success rate of pulp amputation with MTA for the period of observation.

- Definite conclusions could not be done, because of the small number examined teeth, as well as relatively short follow -up period.

- Vital amputation with MTA requires close stick to the clinical protocol.

- Vital amputation with MTA is a reliable biological method for pulp treatment of primary teeth and could be recommended for the clinical practice.

\section{REFERENCES:}

1. Вутов М.: Детска стоматология, София 1989; 170-178

2. Гатева Н., Р. Кабакчиева: Анатомични особености на временните зъби със значение за протичане на възпалителните заболявания на пулпата. Диагностика на възпалителните заболявания на пулпата във временното съзъбие - обзор. Зъболекарски преглед, 2006; 88(2), стр.121128

3. Гатева Н., Р. Кабакчиева: Методи на лечение на заболяванията на пулпата във временното съзъбие - обзор. Зъболекарски преглед, 2007; 89(2), стр.132 138

4. Гатева Н., Р. Кабакчиева: Методи на лечение на заболяванията на пулпата във временното съзъбие. Методи на пулпотомия във временното съзъбие обзор. Зъболекарски преглед, 2007 ; 89(3), стр.208-218

5. Маслинков Д.: Ръководство за практически упражнения по Детска стоматология, София 1989; 71-75

6. Aeinehchi M, Dadvand S, Fayazi S, Bayat-Movahed S.: Randomized controlled trial of минирал trioxide aggregate ad formocresol for pulpotomy in primary molar teeth. Int Endod J 2007; 40: 261267.

7. Agamy HA, Bakry NS, Mounir MMF, Avery DR.: Comparison of mineral trioxide aggregate and formocresol as pulpcapping agents in pulpotomized primary teeth. Pediatr Dent 2004; 26: 302-309.

8. Ballal S, Venkateshbabu N, Nandini S, Kandaswamy D.: An in vitro study to assess the setting and surface crazing of conventional glass ionomer cement when layered over partially set mineral trioxide aggregate. J Endod 2008; 34: 478-480

9. Barrieshi-Nusair KM, Qudeimat MA.: A prospective clinical study of mineral trioxide aggregate for partial pulpotomy in cariously exposed permanent teeth. J Endod 2006; 32: 731-735.

10. Bates CF, Carnes DL, del Rio CE.: Longitudinal sealing ability of mineral 
trioxide aggregate as a root-end filling material. J Endod. 1996; 22: 575-578

11. Buckley JP.: Rational Treatment for Putrescent Pulps. Dent Rev 1904; 18: $1193-1195$

12. Burnett S., Walker J.: Comparison of ferric sulfate, formocresol and a combination of ferric sulfate/formocresol in primary tooth vital pulpotomies: a retrospective radiographic survey. J Dent Child 2002 69(12): 44-48,

13. Butz Cheryl L.: Die endodontische Behandlung von Milchzдhnen bei Kindern in der Praxis. Endodontie Journal 2004; 4: $18-26$

14. Camilleri J, Montesin FE, Brady K, Sweeney R, Curtis RV, Pitt Ford TR.: The constitution of mineral trioxide aggregate. Dent Mater 2005; 21: 297-303.

15. Carrote P.: Endodontic Treatment for Children. Br Dent J 2005; 198(1): 915

16. Danesh G, Dammaschke T, Gerth HUV, Zandbiglari T, Schafer E.: A comparative study of selected properties of ProRoot mineral trioxide aggregate and two Portland cements. Int Endod J 2006; 39: 213-219.

17. Dean JA., Mack RB., Fulkerson BT., Sanders BJ.: Comparison of Electrical and Formocresol Pulpotomy Procedures in Children. Int J Pediatr Dent 2002; 12 (3): 177-182

18. Duggal M., Day P.: Pulp therapy in primary teeth, In: Welbary R., M. Duggal, M.Hosey, Pediatric Dentistry, Third edition., Oxford, 2005, 164-171

19. Eidelman E, Holan G, Fuks AB.: Mineral trioxide aggregate vs. formocresol in pulpotomized primary molars: a preliminary report. Pediatr Dent 2001; 23: 15-18.

20. El-Meligy OA, Avery DR.: Comparison of mineral trioxide aggregate and calcium hydroxide as pulpotomy agents in young permanent teeth (apexogenesis) Pediatr Dent 2006; 28: 399 404.

21. Fadavi S., Anderson A.: A Comparison of the Pulp Response to Freeze-Dried Bone, Calcium Hydroxide and Zinc Oxide-Eugenol in Primary Teeth in two Cynomolgus Monkeys. Pediatric Dentistry 1996; 18: 52-56

22. Farooq N.S., Coll J.A., Kuwabara A., Shelton P.: Success rates of formocresol pulpotomy and indirect pulp therapy in the treatment of deep dentinal caries in primary teeth. Pediatric Dentistry 2000; 22(4): 278-286
23. Farsi N., Alamoudi N., Khalid Balto K., Mushayt A.: Success of mineral trioxide aggregate in pulpotomized primary molars. J Clin Pediatr Dent 2005; 29(4): 307-312

24. Fischer EJ., Arens DE., Miller CH.: Bacterial leakage of mineral trioxide aggregate as compared with zincfree amalgam, intermediate restorative material, and Super-EBA as a root-end filling material. J Endod. 1998; 24: 176-179.

25. Foreman PC., Barnes IE.: A Review of Calcium Hydroxide. Int Endod J 1990; 23: 283-297

26. Fuks A.: Pulp Therapy for the Primary Dentition, In: Pinkham J., Pediatric Dentistry: Infancy Throught Adolescence, Fourth Edition, 2005; 375- 393

27. Garbers Ag.: Vergleich zweier Pulpotomietechniken im Milchgebisses. Eine klinische Studie; Dissertation 2004, Medizinische Fakultдt der Universitдt Monchen, Deutschland

28. Guelmann M., Fair J., Turner C., Courts J.F.: The success of emergency pulpotomies in primary molars. Pediatric Dentistry 2002; 24(3): 217-221

29. Holan G., Eidelman E., Fuks A.B.: Long-term Evaluation of Pulpotomy in Primary Molars Using Mineral Trioxide Aggregate or Formocresol. Pediatric Dentistry 2005; 27(2): 129-136

30. Holland R., de Souza V., Murrata SS., Nery MJ., Bernabe PF., Otoboni JA at all.: Healing Process of Dog Dental Pulp after Pulpotomy and Pulp Covering with MTA or Portland Cement. Brazilian Dental Journal 2001;12: 109-113

31. Holland R., de Souza V., Nery MJ., Otoboni FJA., Bernabe PF., Junior ED.: Reaction of rat connective tissue to implanted dentin tubes filled with mineral trioxide aggregate or calcium hydroxide. J Endod. 1999; 25: 161-166.

32. Hunter ML, Hunter B.: Vital pulpotomy in the primary dentition attitudes and practices on specialists in paediatric dentistry practicing in the United Kingdom. Int J Paediatr Dent 2003 13: 246-250

33. Kettering JD, Torabinejad M.: Investigation of mutagenecity and mineral trioxide aggregate and other commonly used root-end filling materials. J Endod 1995; 21: 537-539.

34. Kilpatrick N., Seow WK., Cameron A., Widmer R.: Pulp therapy for primary and young permanent teeth, In: Cameron A.,R.Widmer, Handbook of Pediatric Dentistry, second edition, Mosby, 2003,
$71-83$

35. Koh ET, McDonald F, Pitt Ford TR, Torabinejad M.: Cellular response to mineral trioxide aggregate. J Endod. 1998;24:543-547.

36. Lewis B.: Formaldehyde in Dentistry: A Review for the Millenium. J Clin Pediatr. Dent 1998; 22: 177 - 186

37. Loh A., O'Hoy P., Tran X., Charles R., Hughes A., Kubo K., Messer B.L.: Evidence-based Assessment: Evaluation of the Formocresol Versus Ferric Sulfate Primary Molar Pulpotomy. Pediatr Dent. 2004; 26: 401-409

38. Maroto M, Barberia E, Planells P, Garcia-Godoy F.: Dentin bridge formation after mineral trioxide aggregate (MTA) pulpotomies in primary teeth. Am J Dent 2005; 18: 151-154.

39. Maroto M, Barberia E, Vera V, Garcia-Godoy F.: Mineral trioxide aggregate as pulp dressing agent in pulpotomy treatment of primary molars: 42-month clinical study. Am J Dent 2007; 20: 283-286.

40. McDonald, R. E., D. R. Avery, J. A. Dean, Dentistry for the Child and Adolescent, VIII ed., Mosby, 2004, p.388413

41. Moretti ABS, Sakai VT, Oliveira TM, et al.: The effectiveness of mineral trioxide aggregate, calcium hydroxide and formocresol for pulpotomies in primary teeth. Int Endod J 2008; 41: 547-555.

42. Nandini S, Ballal S, Kandaswamy D.: Influence of glass-ionomer cement on the interface and setting reaction of mineral trioxide aggregate when used as a furcal repair material using laser Raman spectroscopic analysis. J Endod 2006; 33: 167172

43. Noorollahain H.: Comparison of mineral trioxide aggregate and formocresol as pulp medicaments for pulpotomies in primary molars. Br Dent J 2008; 204: Published online: 18 April 2008 doi:10.1038/sj.bdj. 2008.319

44. Originating Committee, Clinicl Affairs Committee - Pulp Therapy Silcommittee. Guideline on Pulp Therapy for Primary and Young Permanent Teeth. Pediatric Dentistry 2004\2005 Reference Manual, 26 (7): 115-119

45. Osario RM., Hefti A., Vertucci FJ., Shawley AL.: Cytotoxicity of endodontic materials. J Endod 1998; 24: 91-96.

46. Peng L., Ye L., Tan H, Zhou X, Evaluation of the formocresol versus mineral trioxide aggregate primary molar pulpotomy: a meta-analysis. Oral Surg, 
Oral Med, Oral Pathol, Oral Radiol Endod. 2006 Dec; 102(6):e40-44

47. Percinoto C., Castro AM., Pinto LM.: Clinical and radiographic evaluation of pulpotomies employing calcium hydroxide and trioxide mineral aggregate. Gen Dent 2006; 54: 258-261.

48. Ranly DM., Garsia-Godoy F.: Current and Potential Pulp Therapies for Primary and Young Permanent Teeth. J Dent 2000; 28: 153-161

49. Roberts HW, Toth JM, Berzins DW, Charlton DG.: Mineral trioxide aggregate material use in endodontic treatment: a review of the literature. Dent Mater 2008; 24: 149-164.

50. Ruemping DR., Morton TH., Anderson MW.: Eletrosurgical Pulpotomy in Primates-a Comparison with Formocresol Pulpotomy. Pediatr Dent 1983; 5: 14-18

51. Salako N., Joseph B., Ritwik P., Salonen J., John P., Junaid TA.: Comparison of bioactive glass, mineral trioxide aggregate, ferric sulphate and formocresol as pulpotomy agents in rat molar. Dent Traumatol 2003; 19: 314-320.

52. Saris S., Tahmassebi JF., Duggal MS., Cross I.: A clinical evaluation of mineral trioxide aggregate for root-end closure of non-vital immature permanent incisors in children - a pilot study. Dent Traumatol 2008; 24: 79-85.

53. Schwarz R., Mauger M., Clement D., Walker W.: Mineral trioxide aggregate: a new material for endodontics. JADA 1999; 130: 967-975

54. Simon S., Rilliard F., Berdel A., Machtou P.: The use of mineral trioxide aggregate in one-visit apexification treatment: a prospective study. Int Endod J 2007; 40: 186-197.

55. Srinivasan V., Patchett CL., Waterhouse PJ.: Is there Life after Buckley's Formocresol? Part I - a Narrative Review of Alternative Interactions and materials. Int J Ped Dent 2006; 16: $117-127$

56. Srinivasan V., Waterhouse P., Whitworth J.: Mineral trioxide aggregate in paediatric dentistry. International Journal of Paediatric Dentistry 2009; 19: 34-47

57. Subramaniam P., Konde S., Mathew S., Sugnani S: Mineral trioxide aggregate as pulp capping agent for primary teeth pulpotomy: 2 year follow up study. J Clin Pediatr Dent.; 2009: 33(4):311-4

58. Torabinejad M., Hong CU., Lee SJ., Monsef M., Pitt Ford TR.: Investigation of mineral trioxide aggregate for root-end filling in dogs. J Endod. 1995;21:603-608.

59. Torabinejad M., Hong CU., McDonald F., Pitt Ford TR.: Physical and chemical properties of a new root-end filling material. J Endod 1995; 21: 349-353 60. Torabinejad M., Pitt Ford TR., McKendry DJ., Abedi HR., Miller DA., Kariyawasam SP.: Histologic assessmen of mineral trioxide aggregate as a root-end fillingin monkeys. J Endod. 1997; 23: 225 228

61. Torabinejad M., Rastegar AF., Kettering JD., Pitt Ford TR.: Bacterial leakage of mineral trioxide aggregate as a root-end filling material. J Endod. 1995; 21 : 109-112.

62. Tunc ES., Sonmez IS., Bayrak S., Egilmez T.: The evaluation of bond strength of a composite and a compomer to white mineral trioxide aggregate with two different bonding systems. J Endod 2008; 34: 603-605.

63. UK National Clinical Guidelines in Paediatric Dentistry. Int J Paediatric Dentistry 2000; 10 (3): 248-252

64. Walker MP., Diliberto A., Lee C.: Effect of setting conditions on mineral trioxide aggregate flexural strength. J Endod 2006; 32: 334-336

65. Waterhouse PJ., Nunn JH., Whitworth JM., Soames JV.: Primary Molar Pulp Therapy-Histological Evaluation of Failure. Int Paed Dent 2000; 10 (4): 313-324

66. Winters J., Cameron A., Widmer R.: Pulp therapy for primary and immature permanent teeth, In: Cameron A., Nandbook of pediatric dentistry, third edition, Mosby, 2008, 95-113

67. Witherspoon DE., Small JC., Harris GZ.: Mineral trioxide aggregate pulpotomies: a case series outcome assessment. JADA 2006; 137: 610-618

\author{
Address for correspondence: \\ Assoc. prof. Dr. R. Kabaktchieva \\ Department of Pediatric Dentistry, Faculty of Dental Medicine, \\ Medical University of Sofia, \\ 1, Georgi Sofiiski Str., Sofia, Bulgaria \\ E-mail: r_kabaktchieva@mail.bg
}

